that position during 1886 and 1887 . In 1887 he was elected representative, and was re-elected in 1889, and again in 1903, serving in the Twenty-second, Twenty-third, Thirtieth and Thirty-first general assemblies.

John Hexpy Minis was born near Economy, Wayne County, Indiana, October 31, 1847, and died at Redfield, Iowa, January 18, 1931. In 1855 he was with his parents when they removed to a farm north of the present town of Redfield, Dallas County, Iowa. When only seventeen years old, or on December 27, 1864, he enlisted in Company H, Thirtyninth Iowa Infantry, shared marches with Sherman's Army in the last days of the war, and was mustered out July 12, 1865. Returning home, with the exception of a few years when he was a railway mail clerk, he followed farming until 1889 when he became editor and publisher of the Redfeld Clipper, in which business he continued several years. In his later life he was for a time connected with the oil inspection service of the state. In 1916 he was elected commander of the Iowa Department, Grand Army of the Republic, and served one year. He was prominent in the national organization of that order, being chief of staff to the national commander at the time of his death.

Frank N. Buckingham was born in Dekalb County, Illinois, March 26, 1857, and died in Alta, Iowa, January 27, 1931. After reaching manhood he clerked in a store in Somonauk, Dekalb County, and later was manager of a store, but early became a farmer. In 1882 he removed to Elk Township, Buena Vista County, Iowa, where he followed farming and stockraising until about ten years before his death when he became a resident of Alta. He occupied several positions of trust in Elk Township and in 1904 was elected representative and served in the Thirtieth and Thirty-first general assemblies. He was a member of the subcommittee that prepared the drainage bill that was enacted into law during those sessions, which had so much to do with reclaiming and making productive large portions of northwestern Iowa.

\title{
GEORGE H. VAN HOUTEN WAS SECRETARY OF THE STATE FAIR
}

Our good friend, J. P. Mullen, of Fonda, calls our attention to the fact that in the notable death sketch of George H. Van Houten, published in the January Annals, we omitted one of his important activities, that of secretary of the Iowa State Fair. We find Mr. Van Houten occupied that position from January 12,1899 , to December 12, 1901, or almost three years, which would cover the fairs of 1899,1900 , and 1901. The fields of his usefulness to the people of the state were indeed many. 
Copyright of Annals of Iowa is the property of State of Iowa, by \& through the State Historical Society of Iowa and its content may not be copied or emailed to multiple sites or posted to a listserv without the copyright holder's express written permission. However, users may print, download, or email articles for individual use. 